\title{
HOW TO COMPREHEND THE SIMILARITY BETWEEN HEBREW BIBLE AND THE QUR'AN? THE INTERTEXTUALITY BETWEEN PSALM 136 AND Q. 55 (AL-RAHMAN)
}

\author{
Lien Iffah Naf'atu Fina \\ State Islamic University (UIN) Sunan Kalijaga Yogyakarta \\ lieniffahnf@gmail.com
}

\begin{abstract}
Psalm 136 and Q. 55 have a unique similarity in which the two texts contain continuous refrain, repeated twenty-two times in the case of Psalm and thirty-one times in Q. 55. The extensive refrain in Psalm 136 is unique in the Psalm corpus and while there are three other chapters in the Qur'an containing refrain, the case of Q. 55 is the most elaborated one. Furthermore, the refrain in the two texts composes a similar theme, namely divine grace and mercy. This paper is an attempt to present some possible answers of how to understand the striking similarity between the two texts. It starts with the general explanation of the relation between Psalms and the Qur'an followed by brief interpretations of the respective text from its own tradition. In the following, the comparative study of the texts is presented. Finally, it ends with a general reflection of some approaches in the intertextual study between Psalm 136 and Q. 55 and the Bible and the Qur'an in general.
\end{abstract}

Keywords: Psalm 136, Qur'an 55, intertextuality

\section{Introduction}

There are vast Qur'anic verses telling that the Qur'an is "merely" a continuation of previous scriptures: Tawrah, Injil, and Zabur. In Q. 17:55, Zabur is designated as a scripture revealed to David. In another verse (Q. 21:105), the Qur'an mentions a perfect literal reference to Ps 7:9. While to what extent Zabur refers to Psalm is debatable among scholars, this Qur'anic description seems to confirm one theory of Psalm in the Jewish community, namely that the book of Psalm to David is like Torah to Moses. (Uriel Simon, 1991)

Psalm 136 and Q. 55 have a unique similarity in which the two texts contain continuous refrain, repeated twenty-two times in the case of Psalm and thirty-one times in Q. 55. The extensive refrain in Psalm 136 is unique in the Psalm corpus and while there are three other chapters in the Qur'an containing refrain, the case of Q. 55 is the most elaborated one. (Angelika Neuwith, 1998: 395-396.). Furthermore, the refrain in the two texts composes a similar theme, namely divine grace and mercy. It is "for his steadfast love endures forever" in Psalm 136 and "Which, then, of your Lord's blessings do you both deny?" in Q. 55. This paper is an attempt to present some possible answers of how to understand the striking similarity between the two texts.

This paper starts with the general explanation of the relation between Psalms and the Qur'an followed by brief interpretations of the respective text from its own tradition. In the following, the comparative study of the texts, their content and form, is presented. Finally, several approaches in the intertextual study between Psalm 136 and Q. 55 and the Bible and the Qur' an, in general, are elaborated to understand the similarities between the two texts. 


\section{The Texts in Comparison}

From a general look, the two texts share some similarities: (1) refrains expressing similar themes, namely God's bounties and mercy; and (2) identical structure: introduction formed in the invitation to praise God, God's wonders in the universe which making the acting of God in the following sections perceptible, description of God's acting and power for mankind demonstrating God's violence and blessings, and closing. In the following, the comparative investigation of the two texts is presented in some topics

As mentioned earlier, the two texts contain continuous refrain. The Psalm, yet, presents the refrain since the beginning, while in Q. 55, the refrain starts in the v. 13. Furthermore, the refrain in Psalm 136 is hymnic in nature; probably it is due to its function as a liturgical text. In Q. 55, it is a rhetorical question addressing both mankind and jinn (demons). Both refrains, which are thematically and semantically identical, perform as the reminder of divine signs that can be perceived by the mankind in the world.

In both texts, God is depicted as the creator of the universe and the source of all life. Mankind is totally helpless and dependent before him. Yet, while in Psalm 136 it is purely served as the description of the signs of God's mercy and power, in the Q.55, while it is vastly more elaborative, it is also meant to envisage the balance and justice in the order of the universe as an ideal inspiration of God's command for the mankind not to transgress the balance and act according the order that God has commanded.

In Psalm 136, besides His identity of God of nature, He also "works actively and decisively in the affairs of nation and men" in the world, (George S. Gunn, 1956: 50) which is not the case in Q. 55. In the latter, the discourse is lifted to the mythic future or eschatology. The focus of Psalm 136 is unique and close divine-human relationship, while in Q. 55, the relation maintained is between the world order and the accountability of mankind before God in the Day of Judgment. (Neuwith, 1998: 399) The concept of eschatology or the afterlife was absent among the people of Israel.

What about the idea of God as the Redeemer? In Psalm 136, it is said "It is $\mathrm{He}$ who remembered us in our low estate... and rescued us from our foes." Following the interpretation of Herder, this passage can be understood that God releases Israel from her foes despite the fact that her people once became unfaithful to God. In Q. 55, this notion of God forgiving in the history is not apparent. In the end, the two texts talk about retribution theology, yet manifested in the different realm. In the Psalm, it is revealed in the human history. The Qur'an, differently, talks about the eschatological retribution. Furthermore, in the case of Psalm, this theology is afflicted human only, particularly from the lens of the history of the people of Israel. In Q. 55, eschatological retribution encompasses both human in general and extra-human (jinn) widening the scope of discourse in the Psalm.

\section{Several Approaches to the Similarity of the Two Texts}

The first approach is concluding that Muhammad, as said by Hartwig Hirschfield and Heinrich Speyer, having heard the Psalm, used it as an inspiration for his preaching or that the Qur'anic reflection of Psalms was a form of "auctorial revision" of the text. On the other place, Wansbrough stated that Q. 55 imitated the formula of a litany. Furthermore, Richard Bell asserts that the eschatological portion,

which is absent in Psalm 136, was a later addition. (Richard Bell, 1953: 584) This polemical stance has been criticized by contemporary Jewish, Christian, Muslim scholars, such as Angelika Neuwirth, Michael Marx, Nicolai Sinai, Oliver Leaman, Walid Saleh and Abdel Haleem. 
As a response to the polemical approach, Abdel Haleem "defends" Q. 55 from the accusation of imitating Psalm 136, providing a counter opinion ( Haleem, 9395) Haleem stands on the principle that the Qur'an does not need previous scriptures or surrounding texts to interpret it, a stance common among Qur'anic scholars. The historical question on the availability of Psalm in the milieu of Qur'anic revelation is out of his interest.

On the other hand, Angelika Neuwirth, continuing the previous historical approach and yet understand it from a different paradigm insists that there is a historical connection between Psalm 136 and Q. 55. Her proposal is quite new in the realm of Biblical-Qur'anic studies and challenges the well-established interpretive methods in the two traditions. She situates the Qur'an as "a text documenting a creative reworking of Late Antique culture," which is "a pluri- cultural milieu."(Neuwirth, 2008: 124) Thus, it assumes that the audiences of the Qur'an were familiar with Psalm 136. Neuwirth states that Q. 55 is not an imitation or paraphrase of Psalm 136, since the two texts' vision of history, as analyzed above, is completely different. Thus, as she asserts, Q. 55 is a rereading, exegesis or comment of it (Neuwirth, 414)Her historical assumption is the fact that Psalm was vastly used in both Jewish and Christian rituals, brought by churches or synagogues in the surrounding area of Arabian Peninsula. (Neuwirth, 735-736)

It is true that the challenge of Neuwirth's historical assumption is to continuously provide historical legitimation of the possibility of the audiences of the Qur'an to having heard or been familiar with the Biblical text. Afnan Fanani highlights this issue stating that it is anachronistic since there was no Arabic Psalm available in the period of Qur'anic revelation (Fanani, 90-91) · Yet, with regard to the case of Psalm 136, Neuwirth insists that even though the Arabic written translation of the text was not available, "one has to assume that they were transmitted to their Arabic speaking recipients by oral."( Neuwirth, 735-736)

\section{Conclusion}

Above description shows the striking thematic and semantic connection between the two texts. Scholars of Biblical and Qur'anic studies came to different approaches of how to understand this phenomenon. First, Q.55 is an imitation of Psalm 136. Second, there is no need to find a historical explanation of the similarities; in fact, the difference is more apparent than the similarities. Third, the Qur'an independently rereads Psalm 136 and provide counter narrative on the topic of eschatology. The latter analysis of the relation between the Psalm corpus and the Qur'an, Neuwirth has brought the Biblical-Qur'anic scholarship into an idea that to interpret them, scholars should assume that the two texts are dependent one another.

\section{References}

Allen, Leslie C. 198. Word Biblical Commentary Volume 21: Psalms 101-150, Waco: Woorld Publisher.

Bell, Richard. 1953. Introduction to the Qur'an, Edinburgh: The University ress.

Bergant, Dianne. 2013. Psalms 73-150, Collegeville: Liturgical Press.

Booij, TH. 2010. "Psalms 120-136: Songs for A great Festivals," in Biblica, January (1)

Crenshaw, James L. 2001. The Psalms: An Introduction, Cambridge: WM. B. Eerdmans Publishing.

Fatani, Afnan H. 2006 “Aya," in Oliver Leaman (ed.), The Qur'an: an Encyclopedia, London and New York: Routledge. 
Gunn, George S. 1956. God in the Psalms, Edinburgh: The Saint Andrew Press.

Haleem, M.A.S. Abdel. 1993. "Context and Internal Relationships: Keys to Qur'anic Exegesis," in G.R. Hawting dan Abdul-Kader A. Shareef, Approaches to the Qur'an, London and New York: Routlegde.

. 2004. The Qur'an: A New Translation by M.A.S. Abdel Haleem, Oxford: Oxford University Press.

Jerome, St. 1964. The Homilies of Saint Jerome Volume I (1-59 on the Psalms), trans. Sister Marie Liguori Ewald, Washington: The Catholic University of America Press.

Kalt, Edmund (ed.). 1961. Herder's Commentary on the Psalms, Westminster: The Newman Press.

Knight, George A. F. 1983. Psalms: Volume 2, Edinburgh and Philadelphia: The Saint Andrew Press and The Westminster Press,.

Maududi, Abul A'la. 1999. The Meaning of the Qur'an Vol. V, Lahore: Islamic Publication.

Meeks, Wayne A. (ed.). 1989. The Herper Collins Study Bible: New Revisedm Standard Version with the Apocryphal/Deuterocanonical Books, London: HerperCollins Publisher.

Miller, Patrick D. 1995. "Between Text and Sermon: Psalm 136: 1-9, 23-26," in Interpretation, October (1)

Neuwirth, Angelika. 1998. "Qur'anic Literary Structure Revisited: Surat al-Rahman between Mythic Account and Decodation of Myth, 2004," in Stefan Wild (ed.), Story-telling in the Framework on non-Fictional Arabic Literarture, Wiesbaden,. . "Rhetoric and the Qur'an" in Jane D. McAuliffe (ed.), Encyclopaedia of the Qur'an, Vol. 4, Leiden: E.J. Brill.

. 2008. "Two Views of History and Human Future: Qur'anic and Biblical Renderings of Divine Promises," in Journal of Qur'anic Studies, Vol. X, Issue. 1. 